\title{
Correction to: Decolonizing recordkeeping and archival praxis in childhood out-of-home Care and Indigenous archival collections
}

\author{
Sue McKemmish ${ }^{1}$ (D) Jane Bone ${ }^{2}$ (D) Joanne Evans ${ }^{1}$ (D) Frank Golding ${ }^{3}$. \\ Antonina Lewis $^{1}\left({ }^{\circ}\right.$. Gregory Rolan ${ }^{1}$ (10) Kirsten Thorpe ${ }^{1}$ (I) . \\ Jacqueline Wilson ${ }^{3}$ (1)
}

Published online: 17 March 2020

(c) Springer Nature B.V. 2020

\section{Correction to: Archival Science (2020) 20:21-49 https://doi.org/10.1007/s10502-019-09321-z}

In the original publication of the article, the term "Indigenous" in the title was not capitalized. As the article is specifically referring to Indigenous people in Australia, the correct article title should be as given below:

The original article can be found online at https://doi.org/10.1007/s10502-019-09321-z.

\author{
Sue McKemmish \\ sue.mckemmish@monash.edu \\ Jane Bone \\ jane.bone@monash.edu \\ Joanne Evans \\ joanne.evans@monash.edu \\ Frank Golding \\ fgolding@bigpond.net.au \\ Antonina Lewis \\ draylewis@gmail.com \\ Gregory Rolan \\ greg.rolan@monash.edu \\ Kirsten Thorpe \\ kirsten.thorpe@monash.edu \\ Jacqueline Wilson \\ jz.wilson@federation.edu.au
}

1 Centre for Organisational and Social Informatics, Monash University, 900 Dandenong Road, Caulfield East, VIC 3145, Australia

2 Faculty of Education, Monash University, McMahons Road, Frankston, VIC 3199, Australia

3 Collaborative Research Centre in Australian History (CRCAH), Federation University Australia, SMB Campus, Ballarat, VIC 3353, Australia 
"Decolonizing recordkeeping and archival praxis in childhood out-of-home Care and Indigenous archival collections".

Publisher's Note Springer Nature remains neutral with regard to jurisdictional claims in published maps and institutional affiliations. 